\title{
Pembelajaran IPA Secara Dwibahasa Melalui MetodeBercerita untuk Meningkatkan Multiple Intelligences Siswa SD Laboratorium UPI Kampus Cibiru
}

\author{
Novi Yanthi
}

\begin{abstract}
Abstrak
Penelitian ini dilatarbelakangi oleh munculnya tren di bidang pendidikan dasar, yaitu proses pembelajaran di sekolah dasar yang mengajarkan materi subjek dalam bahasa Inggris sebagai media instruksi. Sekolah dasar di berbagai negara seperti Singapura, Cina, Malaysia, dan bahkan di Inggris (Dedezade: 2006) sekalipun telah mengaplikasikan bahasa Inggris sebagai media instruksi dalam mata pelajaran Matematika dan IPA secara dwibahasa. Tren pendidikan dasar ini juga sudah merambah ke Indonesia. Oleh karenanya, banyak sekolah dasar di Indonesia yang menetapkan kebijakan bahwa guru yang mengajar di satuan pendidikan tersebut harus memiliki keterampilan dasar bahasa Inggris agar mampu mengajarkan materi subjek menggunakan bahasa Inggris. Konsekuensi dari hal tersebut adalah guru sekolah dasar sebagai guru kelas tak hanya dituntut untuk dapat menguasai berbagai konsep materi subjek, namun harus pula terampil mengajarkannya dalam bahasa Inggris. Tujuan penelitian kali ini adalah untuk (1) mengetahui kendala yang dihadapi guru di kelas pada pembelajaran konsep IPA mengenai bagian tubuh hewan secara dwibahasa di kelas 2 SD melalui metode bercerita dan (2) mengetahui aspek multiple intelligences yang mana yang dapat ditingkatkan melalui pembelajaran IPA secara dwibahasa dengan metode bercerita. Peneliti memperhatikan proses pembelajaran IPA secara dwibahasa pada situasi natural melalui interaksi antara guru dengan siswa kelas 2 SD laboratorium UPI Kampus Cibiru. Hasil penelitian menunjukkan bahwa (1) kemampuan guru dalam membelajarkan konsep IPA secara dwibahasa melalui metode bercerita masih harus ditingkatkan. Guru terpaku pada RPP yang telah disusun sehingga tidak dapat mengeksplorasi dan mengembangkan kegiatan bercerita dalam pembelajaran secara terpadu. Hal ini disebabkan keterampilan bahasa Inggris guru masih kurang, yaitu dalam hal perbendaharaan kosakata, pemilihan kata yang sesuai dengan terminologi IPA, dan pelafalan kata sehingga menimbulkan kesalahan konsep IPA. Kendala-kendala tersebut menyebabkan kurangnya kepercayaan diri guru saat melakukan tugas mengajar. (2) Pembelajaran IPA secara dwibahasa dengan metode bercerita dapat dijadikan alternatif upaya meningkatkan multiple intelligences siswa SD, yaitu kecerdasan naturalis, linguistik, visual-spasial, dan interpersonal. Saran yang diajukan peneliti untuk meningkatkan kemampuan guru mengorganisasikan pembelajaran dwibahasa adalah dilaksanakannya program pelatihan atau seminar bagi kelompok guru SD. Pelatihan seperti ini dapat dilakukan melalui hubungan kemitraan antara kelompok guru dalam satuan pendidikan dengan LPTK penyelenggara program PGSD, salah satunya adalah UPI Kampus Cibiru.
\end{abstract}

\section{Latar Belakang}

$$
\text { Pembelajaran }
$$

IImu

Pengetahuan Alam (IPA) dengan media instruksi bahasa Inggris telah banyak dilakukan pada siswa-siswa yang bukan penutur asli bahasa Inggris di berbagai negara, seperti Singapura, Cina, Malaysia, dan bahkan di Inggris sekalipun. Pada saat ini, hal tersebut juga telah menjadi isu tren di sekolah dasar di Indonesia. Saat ini, pembangunan

sekolah-sekolah berstandar internasional semakin menjamur di berbagai kota besar Indonesia. Beranjak dari pemahaman bahwa guru sekolah dasar adalah guru kelas, maka guru harus mampu mengajarkan berbagai materi subjek, termasuk di dalamnya IPA dan bahasa Inggris.

Berdasarkan hasil penelitian mengenai peningkatan multiple intelligences siswa SD Laboratorium UPI 
Kampus Cibiru melalui pembelajaran IPA secara dwibahasa (Yuliariatiningsih, 2007) dapat meningkatkan kecerdasan majemuk siswa SD dengan menggunakan media gambar berwarna dan metode tanya jawab, bermain musik, serta bernyanyi. Beranjak dari penelitian tersebut, penelitian yang dilakukan kali ini bertujuan untuk meningkatkan multiple intelligences siswa SD melalui pembelajaran IPA secara dwibahasa menggunakan metode bercerita. Adapun pertanyaan penelitian yang dijawab oleh peneliti adalah:

1. Kendala apa yang dihadapi saat dilakukan pembelajaran konsep IPA secara dwibahasa menggunakan metode bercerita?

2. Aspek multiple intelligences yang manakah yang dapat ditingkatkan melalui pembelajaran konsep IPA secara dwibahasa menggunakan metode bercerita?

\section{Kerangka Teoritik}

Pengembangan kemampuan profesional guru dimaksudkan agar guru tidak hanya mentransfer ilmu dan pengetahuan saja, tetapi juga bagaimana meningkatkan intelektual dan kemampuan diri calon guru/guru SD sesuai dengan masalah-masalah riil dan kompleks yang ada di masyarakat. Pengembangan dam hal ini
profesional guru, dalam hal
keterampilan mengajar guru
merupakan proses yang panjang, berkelanjutan, berkesinambungan, menantang intelektualitas, dan harus dikondisikan dalam situasi riil di kelas.

(Roskos \& Vukelich: 1998).

Hamond dalam bukunya The Powerful Teacher Education (2006) mengemukakan bahwa salah satu kriteria guru yang memiliki pengetahuan dan keterampilan mengajar yang baik adalah mereka yang dapat mengintegrasikan pembelajaran yang memadukan bermacam-macam keterampilan siswa; serta mampu mengajarkan keterampilan berbahasa pada semua tingkatan siswa dan lintas mata pelajaran. Guru SD sebagai guru kelas diharapkan memiliki keterampilan berbahasa Inggris untuk mengajarkan mata pelajaran IPA secara terpadu dengan bahasa Inggris melalui pembelajaran dwibahasa.

Pembelajaran terpadu diyakini dapat meningkatkan pemahaman siswa tentang kedalaman dan keluasan berbagai materi pelajaran yang diintegrasikan. (Fogarty: 1991). Pengajaran IPA dan bahasa Inggris secara terpadu dapat membantu memperdalam pemahaman siswa terhadap isi materi IPA selain meningkatkan kemampuan berbahasa Inggris siswa. Haliwell (1992) dalam bukunya yang berjudul Teaching English in the Primary Classroom bahwa pengajaran materi subjek dengan media instruksi bahasa Inggris (content based english teaching) merupakan cara terbaik yang dapat dilakukan untuk menanamkan pemahaman penguasaan bahasa Inggris secara mendalam pada 
siswa SD (Cameron: 2001). Selain dari itu, pengajaran materi subjek dengan media instruksi bahasa Inggris juga dapat meningkatkan keterampilan berpikir siswa.

Dalam pembelajaran dwibahasa

di SD, guru harus mampu mengorganisasikan pembelajaran yang memungkinkan siswa bekerja secara kolaboratif sehingga tercipta interaksi antar siswa. Guru tidak boleh memaksakan siswa untuk menggunakan bahasa Inggris dalam literatur, mereka harus diberi kesempatan untuk menggunakan bahasa pertamanya (Dedezade: 2006).

Pembelajaran yang dirancang menarik bagi siswa diyakini akan dapat meningkatkan motivasi siswa untuk belajar. Pengorganisasian pembelajaran dengan berbagai metode dan media yang menarik juga diyakini dapat meningkatkan multiple intelligences siswa. Howard Earl Gardner mengemukakan delapan aspek multiple intelligences, yaitu:

1) Kecerdasan linguistik, meliputi kemampuan memahami bahasa verbal dan tulisan, kemampuan mempelajari bahasa, kemampuan menggunakan bahasa untuk mencapai suatu maksud/tujuan, kemampuan menggunakan bahasa secara efektif untuk menjelaskan sesuatu hal, kemampuan mengekspresikan perasaan melalui puisi atau kata-kata, kemampuan mengapresiasi sastra, dan kemampuan mengingat informasi verbal.
2) Kecerdasan logiko-matematis, terdiri atas kemampuan berfikir dan menganalisis permasalahan secara logis, menyelesaikan operasi/soal matematik, meneliti suatu hal dengan metode ilmiah, dan memberikan penjelasan secara deduktif.

3) Kecerdasan musikal, meliputi keterampilan dalam menampilkan, mengekspresikan, dan mengapresiasi karya seni musik.

4) Kecerdasan kinestetik, yaitu kemampuan untuk mengorganisasikan gerak anggota tubuh dan menggunakannya dalam memecahkan permasalahan.

5) Kecerdasan spasial, terdiri atas kemampuan mengenali dan menggunakan pola atau informasi berupa simbol visual.

6) Kecerdasan interpersonal, yaitu kemampuan memahami perasaan, keinginan, dan motif yang dimiliki orang lain dalam hubungan sosial.

7) Kecerdasan intrapersonal, meliputi kemampuan memahami konsep diri, mengatur diri, dan mengembangkan kerpibadian yang baik.

8) Kecerdasan naturalis, meliputi kemampuan mengenali, mengelompokkan, dan memberikan penjelasan secara rasional atas peristiwa-peristiwa yang terjadi di alam dalam kehidupan sehari-hari.

(http://.www.infed.org/thinkers/gardner.ht $\underline{\mathrm{m}}, 2008)$

Untuk meningkatkan keseluruh atau sebagian multiple intelligences siswa, diperlukan kemampuan guru dalam 
mengorganisasikan kurikulum melalui pemilihan pendekatan pembelajaran, metode, media, dan teknik assesssmen yang sesuai dengan beragam kebutuhan dan karakteristik siswa (http://.www.infed.org/thinkers/gardne r.htm, 2008).

\section{Metodologi Penelitian}

Penelitian ini secara kolaboratif mempelajari bagaimana implementasi pembelajaran IPA SD kelas 2 pada konsep bagian tubuh hewan secara dwibahasa. Metodologi penelitian yang dipilih adalah kualititatif naturalistik yang difokuskan pada situasi dan kondisi riil dan alami di kelas dalam pembelajaran IPA. Penelitian ini melibatkan guru dan siswa SD Laboratorium UPI Kampus Cibiru dalam interaksi aktif selama proses pembelajaran IPA berlangsung.

\section{Subjek dan Objek Penelitian}

Subjek dalam penelitian ini adalah guru yang merupakan mahasiswa program S1 PGSD UPI Kampus Cibiru dan siswa kelas 2 SD Laboratorium UPI Kampus Cibiru. Sedangkan objek dalam penelitian ini adalah kemampuan guru membelajarkan konsep IPA secara secara dwibahasa menggunakan metode bercerita dan multiple intelligences siswa SD Kelas 2.

\section{Prosedur Penelitian}

Prosedur penelitian yang dilakukan meliputi tahapan-tahapan: (1) perencanaan (diskusi rencana penelitian antara tim dosen bahasa Inggris dan IPA, merancang silabus, menyusun jadwal, dan menyiapkan bahan belajar); (2) implementasi rencana penelitian (orientasi dan pelaksanaan pembelajaran IPA); dan (3) analisis data penelitian.

\section{Instrumen Penelitian}

Instrumen yang dikembangkan dalam penelitian ini adalah: (1) Lembar observasi penilaian kinerja guru (APKG 2), (2) Lembar penilaian proses untuk siswa, (3) Catatan lapangan berupa anekdot yang merekam kejadian-kejadian yang dianggap perlu dan kritis untuk didiskusikan selama pembelajaran berlangsung, (4) Lembar panduan wawancara dengan guru setelah pembelajaran berakhir, (5) Rekaman video pembelajaran IPA di kelas 2 SD Laboratorium UPI Kampus Cibiru

\section{Hasil dan Pembahasan}

Pada saat guru menyampaikan cerita berjudul Cowy, Goldie, and Birdie, guru tidak melakukan kesalahan karena guru telah berlatih sebelumnya dan cerita yang disusun cukup singkat dan sederhana sehingga mudah dipahami siswa. Siswa sangat antusias menyimak cerita dan melihat media gambar yang digunakan. Dalam bercerita guru melakukan repetisi dan mengajak siswa terlibat aktif melalui kegiatan fisik, seperti meniru suara sapi dan burung, menunjukkan bagian tubuh 
manusia atau hewan, dan menjawab pertanyaan guru.

Namun, saat guru melakukan kegiatan tanya jawab saat bercerita menggunakan bahasa Inggris dalam pembelajaran IPA terdapat beberapa kesalahan yang menyebabkan kesalahan konsep, yaitu:

T: "How many fins does Goldie have? Let's count! One, two, three.."

Ss:" Four..."

$T:$ "Yes, three fins".

Dari dialog yang terjadi antara guru dengan siswa terlihat bahwa guru melakukan kesalahan ketika ingin menunjukkan sirip ikan (pada media wayang) yang berjumlah empat buah. Sirip ikan terdiri atas satu sirip punggung, dua sirip pinggir, dan satu sirip perut. Hal ini membingungkan siswa karena siswa menjawab bahwa sirip ikan ada empat buah, namun guru mengatakan bahwa jumlah sirip ikan ada tiga buah. Akan tetapi, saat siswa dan guru menarik kesimpulan di akhir cerita guru mengatakan bahwa ikan memiliki empat buah sirip.

Selain itu, terdapat kesalahan guru saat permainan untuk mengembangkan pemahaman siswa tentang bagian-bagian tubuh hewan yang ada dalam cerita. Siswa telah dengan benar menunjukkan bagian sayap burung, namun guru mengatakan bahwa gambar tersebut adalah ekor. Media gambar yang digunakan dalam permainan berbeda dengan media yang ada dalam cerita. Kesalahan pelafalan juga terjadi saat guru membimbing siswa untuk membedakan antara feet/foot (telapak kaki) dan leg (kaki). Guru melafalkan feet menjadi fat (lemak/gemuk), yang menimbulkan miskonsepsi.

Berdasarkan temuan tersebut di atas, keterampilan guru mengajarkan konsep IPA secara dwibahasa masih harus ditingkatkan lagi. Berdasarkan hasil wawancara diketahui bahwa guru mampu mengajarkan konsep IPA dalam bahasa Indonesia. Akan tetapi, guru menemui kesulitan pada saat mengajarkan konsep IPA secara dwibahasa. Hal ini disebabkan oleh kurangnya keterampilan berbahasa Inggris yang dimiliki guru sehingga guru kurang memiliki kepercayaan diri untuk mengeksplorasi dan mengembangkan pembelajaran menggunakan berbagai istilah bahasa Inggris yang relevan.

Kurangnya keterampilan bahasa Inggris guru menimbulkan kesalahan konsep IPA yang diajarkan. Keterampilan bahasa Inggris yang dimaksud adalah dalam hal perbendaharaan kosakata bahasa Inggris dan pemilihan kata yang sesuai dengan terminologi IPA. Kedua keterampilan ini saling berhubungan karena seringkali beberapa istilah dalam bahasa Inggris memiliki arti yang sama dalam bahasa Indonesia, hanya terminologi dan konteksnya yang berbeda. Kesalahan pemilihan kata menyebabkan konteks yang ingin diajarkan tidak tersampaikan. Pada akhirnya hal ini menyebabkan miskonsepsi IPA. Miskonsepsi tersebut biasanya akan terus diingat oleh siswa SD karena miskonsepsi berasal dari guru yang dianggap siswa sangat tahu dan memiliki otoritas atas dirinya. Miskonsepsi IPA akan mempengaruhi kemampuan siswa dalam mengasimilasi konsep atau pengetahuan 
baru di masa yang akan datang (Esler \& Esler: 1996).

Berdasarkan hasil penilaian evaluasi akhir siswa diketahui bahwa seluruh siswa memahami materi IPA yang disampaikan guru melalui cerita dalam bahasa Inggris. Siswa dapat mengaplikasikan konsep yang telah dipelajarinya mengenai bagian tubuh hewan dalam kehidupan sehari-hari, ketika mereka menjelaskan bagian tubuh hewan yang terdapat di lingkungan sekitar siswa. Hal ini sesuai dengan pernyataan dari Fogarty (1991), yaitu pembelajaran terpadu dapat meningkatkan pemahaman siswa tentang kedalaman dan keluasan berbagai materi pelajaran yang diintegrasikan.

Pembelajaran IPA secara dwibahasa dengan metode bercerita juga dapat membantu memperdalam pemahaman siswa terhadap konsep bagian tubuh hewan dalam IPA selain meningkatkan kemampuan berbahasa Inggris siswa. Pendapat ini sejalan dengan Haliwell (1992) bahwa pengajaran materi subjek dengan media instruksi bahasa Inggris merupakan cara terbaik yang dapat dilakukan untuk menanamkan pemahaman dan penguasaan bahasa Inggris secara mendalam pada siswa SD.

Pembelajaran IPA secara manipulatif dan terpadu dengan bahasa Inggris memiliki kelebihan yaitu dalam peningkatan perbendaharaan kosakata bahasa Inggris siswa (Esler \& Esler: 1996). Pembelajaran manipulatif yang dilakukan adalah pembelajaran yang menggunakan media wayang yang menarik minat siswa untuk belajar IPA. Melalui eksplorasi dengan menyimak cerita dan mengamati gambar, siswa belajar mengenal kosakata bahasa Inggris bukan hanya sebatas membaca istilah-istilah asing dalam buku teks. Dalam pembelajaran, siswa dilibatkan secara aktif melalui kegiatan fisik.

Rekaman video menunjukkan selama pembelajaran guru memberikan bimbingan pada siswa untuk memperoleh konsep IPA melalui action, mimik, media nyata, dan juga bahasa verbal. Simulator tidak mengajarkan konsep-konsep IPA secara langsung jika siswa menemukan kesulitan dalam memahami istilah bahasa Inggris dalam cerita. Hal ini sesuai dengan pendapat Esler \& Esler (1996) bahwa dalam pembelajaran yang menggunakan definisi ilmiah atau asing bagi siswa, diperlukan keterampilan guru untuk dapat memberikan bimbingan pada siswa melalui bahasa Inggris verbal secara dwibahasa maupun tindakan (mimik atau tingkah laku). Esler \& Esler juga menyatakan bahwa untuk meluruskan miskonsepsi siswa terhadap suatu istilah dapat dilakukan dengan mendefinisikan istilah tersebut dalam bahasa yang dimengerti siswa, atau menghubungkan konsep dengan konteks dalam kehidupan sehari-hari siswa.

Pembelajaran IPA secara dwibahasa pada konsep menganal bagian tubuh hewan dengan metode bercerita dapat meningkatkan multiple intelligences siswa, meliputi kecerdasan naturalis, linguistik, visual-spasial, dan interpersonal. Metode bercerita yang diikuti dengan kegiatan tanya jawab, menyusun puzzle, dan permainan kelompok dirasakan sesuai dengan usia perkembangan psikologis, minat, potensi, dan kebutuhan siswa SD 
kelas 2 dalam mempelajari konsep bagian tubuh hewan. Hal ini sesuai dengan pendapat dari Kornhaber (http://.www.infed.org/thinkers/gardner.ht $\underline{m}$, 2008) bahwa teori multiple intelligences mengakomodasi siswa dengan beragam cara berpikir dan belajar. Dalam hasil penelitian Project Summit (2000) dikemukakan bahwa guru harus mampu mengorganisasikan kurikulum dan assessmen dengan pendekatan pembelajaran yang sesuai sebagai upaya untuk meningkatkan multiple intelligences siswa

(http://.www.infed.org/thinkers/gardner.ht $\underline{m}, 2008)$.

Kecerdasan naturalis dan linguistik siswa dalam penelitian ini ditingkatkan melalui kegiatan menyimak cerita dan diikuti dengan kegiatan tanya jawab mengenai konsep bagian-bagian tubuh hewan dalam bahasa Inggris yang disampaikan guru.

Kecerdasan naturalis yang dimaksud adalah kecerdasan dalam mengenali berbagai jenis hewan melalui kegiatan mengamati, mengelompokkan, dan menganalisis perbedaan bagian-bagian tubuh hewan menggunakan media wayang atau gambar hewan. Hewan yang dipilih merupakan hewan-hewan yang dekat dengan kehidupan sehari-hari siswa. Hal ini sesuai dengan apa yang dikemukakan oleh Smith bahwa kecerdasan naturalis akan berkembang baik bila dalam pembelajaran guru melibatkan hal-hal nyata yang dekat dengan kehidupan di lingkungan sekitar siswa
(http://www.en.wikipedia.org/wiki/Theory of multiple intelligences.htm, 2008).

Kecerdasan lingusitik yang
ditampilkan dalam penelitian adalah
kecerdasan siswa dalam mempelajari
kosakata baru dalam bahasa Inggris yang
berhubungan dengan hewan dan bagian
tubuhnya melalui cerita dan tanya jawab.
Kemampuan siswa dalam memahami cerita
dalam bahasa Inggris menunjukkan bahwa
metode bercerita menggunakan media yang
relevan dapat meningkatkan kecerdasan
linguistik siswa. Repetisi yang dilakukan
guru dalam bercerita dan tanya jawab
membantu siswa untuk mengingat kosakata
dan menggunakannya kembali dalam
konteks yang sesuai dalam kehidupan
sehari-hari

(http://www.en.wikipedia.org/wiki/Theory of multiple intelligences.htm, 2008).

Kecerdasan visual spasial ditingkatkan melalui kegiatan mengamati media pembelajaran berupa wayang atau gambar hewan yang digunakan dalam kegiatan bercerita, kegiatan menyusun puzzle bagian tubuh hewan, dan kegiatan permainan menebak bagian tubuh hewan. Siswa yang memiliki kecerdasan visualspasial baik mampu mengingat bagian tubuh hewan yang ditampilkan melalui wayang dalam cerita. Siswa selanjutnya mampu me-recall memorinya dalam kegiatan menyusun puzzle dan permainan kelompok menebak bagian tubuh hewan. Ini sesuai dengan teori Gardner bahwa siswa yang memiliki kecerdasan visualspasial yang baik memiliki kemampuan lebih baik dalam menyelesaikan puzzle, mengingat simbol-simbol visual, dan 
memiliki

sisi

artistik

(http://www.en.wikipedia.org/wiki/Theory of multiple intelligences.htm, 2008). Hasil penelitian Project Summit (2000) memperkuat temuan penelitian bahwa salah satu faktor yang mendukung keberhasilan upaya meningkatkan multiple intelligences siswa adalah dengan memasukkan unsur seni ke dalam proses pembelajaran baik secara terfragmentasi maupun secara terpadu lintas mata pelajaran.

Kecerdasan interpersonal siswa ditingkatkan melalui kegiatan tanya jawab saat guru bercerita dalam bahasa Inggris, kegiatan kelompok menyelesaikan puzzle bagian tubuh hewan, dan permainan kelompok menebak bagian tubuh hewan. Teori multiple intelligences dari Gardner menyebutkan bahwa kecerdasan interpersonal seseorang dapat ditunjukkan dengan kemampuan memahami perasaan, emosi, temperamen, dan motivasi orang lain, kemampuan bekerjasama dalam kelompok baik sebagai pemimpin maupun anggota, berkomunikasi secara efektif, dan umumnya menyenangi kegiatan diskusi atau debat

(http://www.en.wikipedia.org/wiki/Theory of multiple intelligences.htm, 2008).

\section{Kesimpulan}

1. Kendala yang dihadapi oleh guru saat melakukan pembelajaran IPA disebabkan kurangnya keterampilan berbahasa Inggris, dalam hal perbendaharaan kosakata dan pemilihan kata yang sesuai dengan konteks dan terminologi IPA, serta kesalahan pelafalan. Hal ini menimbulkan kesalahan konsep IPA yang diajarkan.

2. Pembelajaran IPA secara dwibahasa menggunakan metode bercerita dapat meningkatkan kecerdasan naturalis, linguistik, visual-spasial, dan interpersonal siswa.

\section{Saran}

Berdasarkan hasil penelitian yang dilakukan, masih terdapat kekurangankekurangan terutama yang disebabkan kurangnya keterampilan berbahasa Inggris guru. Untuk mengatasi hal tersebut, diajukanlah saran-saran sebagai berikut:

1. Untuk pembiasaan, guru sebaiknya sekalikali melakukan pembelajaran IPA secara dwibahasa agar siswa terbiasa mendengar terminologi IPA dalam bahasa Inggris dan guru pun tidak kaku lagi dalam mengelola pembelajaran secara dwibahasa.

2. Saran yang diajukan peneliti untuk meningkatkan kemampuan guru mengorganisasikan pembelajaran dwibahasa adalah dilaksanakannya program pelatihan atau seminar bagi kelompok guru SD. Pelatihan seperti ini dapat dilakukan melalui hubungan kemitraan antara kelompok guru dalam satuan pendidikan dengan LPTK penyelenggara program PGSD, salah satunya adalah UPI Kampus Cibiru.

\section{Daftar Pustaka}

(tanpa tahun). Theory of Multiple Intelligences. [online]. http://www.en.wikipedia.org/wik i/Theory of multiple intelligence s.htm 
Cameron, Lynne. (2001). Teaching Languages to Young Learners. Cambridge: Cambridge University Press.

Dedezade, K. (2005). Teaching Bilingual Science (Presented at The Multiverse London Regional Workshop II). London: Not Published

Esler \& Esler. (1996). Teaching Elementary Science. USA: Wadsworth Publishing Company

Fogarty, Robin. (1991). How to Integrate the Curricula. USA: IRI/Skylight Publishing, Inc

Gega, Peter C. (1982). Science In Elementary Education. New York : John Wiley and Sons

Halliwell, S. (1992). Teaching English In the Primary Classroom. USA: Longman

Hammond, Linda. D. (2006). Powerful Teacher Education. San Fransisco: John Wiley \& Sons, Inc

Joyce, B. \& Weil, M. (1996). Models of Teaching. USA: Allyn and Bacon

Renner, J. W \& Stafford, Don. G. (1979). Teaching Science in in The Elementary School. New York : Harper \& Row Publishers

Smith, Mark. K. (2008). Howard Gardner and Multiple Intelligences, The Encyclopedia of Informal Education. [online]. http://.www.infed.org/thinkers/g ardner.htm

Tim Dosen Mata Kuliah Pendidikan IPA SD.

(2000). Hand Out Perkuliahan

Pendidikan IPA SD. Tidak diterbitkan

What the Data Really Show: Direct Instruction Really Works! The Dirty Little Secret from the Biggest Education Study Ever. (2008). dalam www.JeffLindsay.com. 
